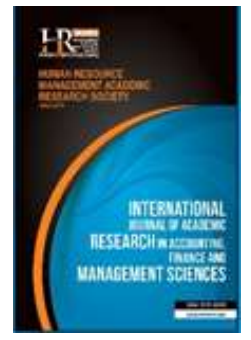

International Journal of Academic Research in Accounting, Finance and Management Sciences

Vol. 9, No.3, July 2019, pp. 104-117

E-ISSN: 2225-8329, P-ISSN: 2308-0337

(C) 2019 HRMARS

www.hrmars.com

To cite this article: Saruchi, S.A., Mohd Zamil' N.A., Basiruddin, R., Ahmad, N. F. G. (2019). Examining the Impact of Corporate Governance on Intellectual Capital: Empirical Evidence of Islamic Banks, International Journal of Academic Research in Accounting, Finance and Management Sciences 9 (3): 104-117,

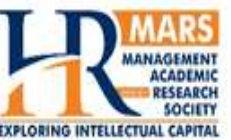

\title{
Examining the Impact of Corporate Governance on Intellectual Capital: Empirical Evidence of Islamic Banks
}

\author{
Sarah Athirah Saruchi ${ }^{1}$, Nor Aiza Mohd Zamil2, \\ Rohaida Basiruddin ${ }^{3}$, Nor Faezah Ghazi Ahmad ${ }^{4}$ \\ 1,2,3,4Azman Hashim International Business School, Universiti Teknologi Malaysia, 54100 Kuala Lumpur, Malaysia, \\ ${ }^{1}$ E-mail: saratirah91@gmail.com, (Corresponding author), ${ }^{2} E$-mail: noraiza@ibs.utm.my, \\ ${ }^{3}$ E-mail: rohaida@ibs.utm.my, ${ }^{4} E$-mail:norfaezahga@gmail.com
}

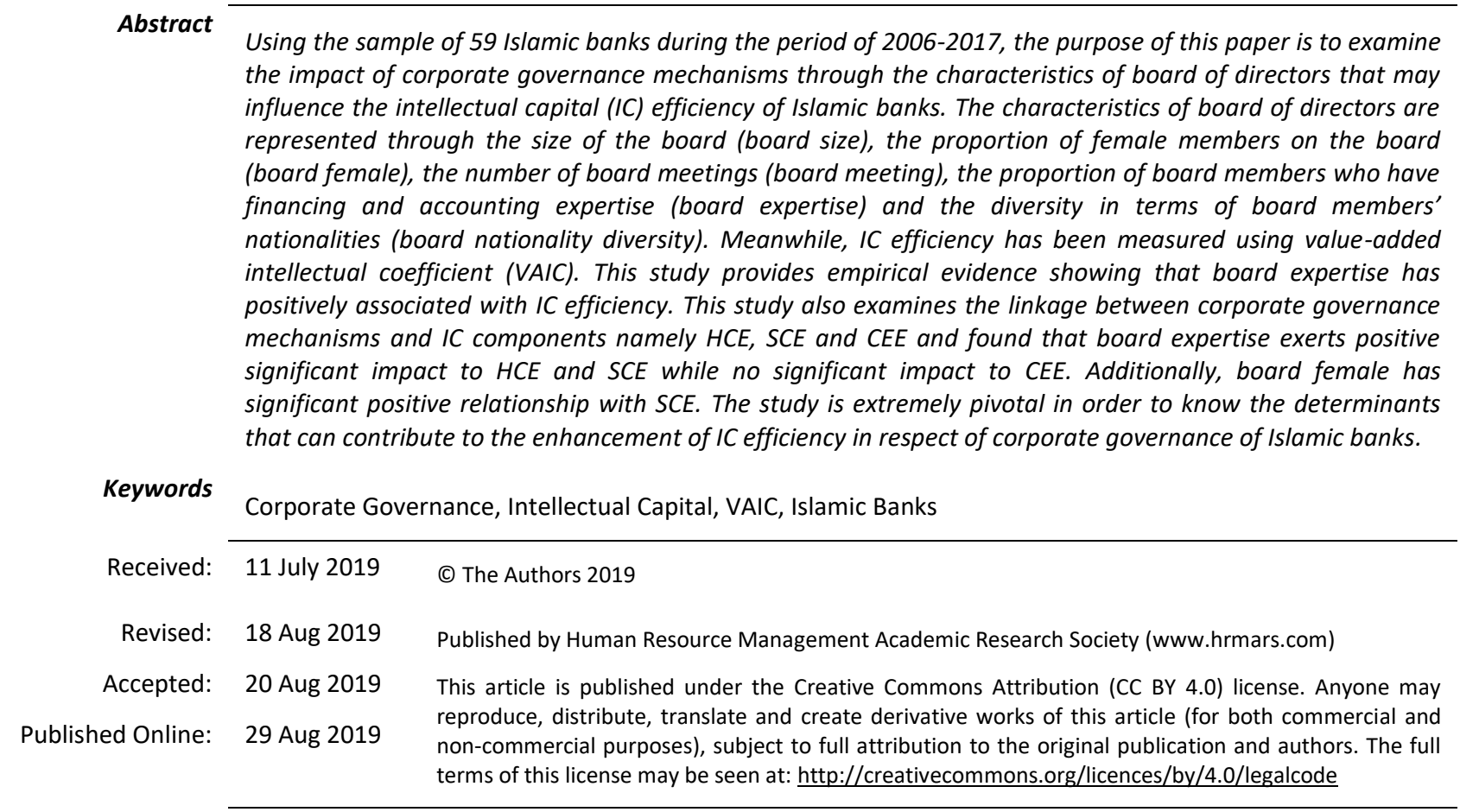

\section{Introduction}

With the passage of time, the surging contour of knowledge based economies has considerably made the organizations nowadays to stop depending solely on physical capital to elevate their organizational performance. In fact, they started to become conscious of an unseen driver that leads to better performance as well, which is intangible asset that famously known as intellectual capital (IC). Thus, it is important to be cognisant of the importance of knowledge creation or in part, the significance of intellectual capital (IC) on financing performance (Nimtrakoon, 2015) which can directly sustain the competitive advantage (Pourmozafari et al., 2014) of particular organisation. Additionally, as highlighted by Barney, Wright, and Ketchen Jr (2001), based on resource-based view theory, every organization possess the resources and capabilities which can be viewed as bundles of tangible and intangible assets where they will be able to create competitive advantage of organization since these resources are valuable, rare, imperfectly imitable, and not substitutable. This is also supported by Ljubojevic et al. (2013), where they 
opined that the competitive advantage of particular organization is manifested by the utilization of unique and exceptional resources, inimitable and valuable. With these characteristics, the organization will be able to sustain their competitive advantage because their resources are hard to be replicated or mimicked by other competitors. This is in concert with the role of intellectual capital that can ensure the value added which is expected to maximize the organizational outcomes via its aforementioned characteristics.

In light of the importance of intellectual capital, it is no surprise that there are bulk of past researches have examining the impact of intellectual capital on performance across different sectors and regions (Amin and Aslam, 2017; Dimitropoulos and Koumanakos, 2015; Mohammad et al., 2018; Saeed et al., 2016; Tran and Vo, 2018) and majority studies found that the more efficient the employment of intellectual capital, the better the organizational performance.

Nonetheless, there is paucity of studies in examining on what are the determinants that can affect IC efficiency even fundamentally; the management of intellectual capital should be identified beforehand. Owing to this issue, there are few studies that examine the impact of corporate governance through the characteristics of board of directors as the mainstay in corporate governance on IC efficiency (M. A. K. M. Al-Musali \& Ku Ismail, 2015; Appuhami and Bhuyan, 2015; Kamath, 2019). This is because as opined Keenan and Aggestam (2001), corporate governance plays a key role to create, develop and leverage IC that embedded in the people, processes and structures within organization. In particular, board of directors as the key players in corporate governance is being mandated to monitor the action of managers. Their existence is entrusted to ascertain the managers perform their responsibilities in pursuit of shareholders' interests.

All the studies reviewed hitherto, there is paucity of studies that attempted to examine on how the corporate governance mechanisms via board characteristics can be linked to IC efficiency (Appuhami and Bhuyan, 2015). Therefore, this study put emphasis on Islamic banking setting as the nexus between governance and intellectual capital study still under-developed in banking sector, and the existing studies are more likely to investigate the relationship between corporate governance and intellectual capital disclosure (Abdul Rashid et al., 2012; Mubaraq and Haji, 2014). As explicated by Nawaz and Haniffa (2017), due to Islamic banking nature, the banks need to develop innovative products differ from the conventional banks, so that, they have to empower their intangible assets like human capital to stay competitive in the market. Thence, this study seeks to measure how the corporate governance mechanisms where the board of directors as the key players, can affect the IC efficiency of Islamic banks. The findings will be of great importance in order for the banks to identify the key characteristics of the board that will be taken care of. The other contribution that this study can offer is to the best of author's knowledge this is the pioneer study that investigate the characteristics of board of directors that exert impact to IC efficiency using a large sample of Islamic banks with longitudinal period of 2006-2017 to take into account the presence of crisis.

\section{Literature Review and Hypotheses Development}

\subsection{Intellectual Capital}

The bulk of past researches oftentimes give the definition of intellectual capital in which lead to incongruity of the definition by the academic scholars. In general parlance, Roos (1998) defines intellectual capital as the summation of human and structural capital. Later, with a more extensive definition, intellectual capital is the intellectual material and property, knowledge, experience and information that can be utilized for wealth creation (Steward, 1997). Adopt a broader picture of IC definition; the millennial researches came out with slightly different interpretation as compared to preceding literatures. Mention (2012, p. 3) in his attempt to provide precise definition of IC stated that IC is "a set of internal and external resources (human, process, IT-based or enabled) that organizations mobilize and articulate, through activities, with other resources (financing and tangible) in order to further generate resources, which can be of tangible, intangible or financing nature, in their pursuit of competitive advantage". Despite the numerous definitions of IC, in essence, IC can be summarized as the intangible assets that comprise of knowledge, experience, customer rapport and infrastructure that elevate the performance of organization due to its ability to create value creation and competitive advantage. 
Congeneric to the definition of intellectual capital, there are no universal classification on the composition of IC and its measurements. In parallel with the past studies, this study follows the majority views which clarify that IC comprises of human capital, structural capital and relational capital. Edvinsson and Stenfelt (1999) then, opined that human capital is based on experience, skills and knowledge. To add up, it can be considered as major and strategic asset for organization (Soheyli et al., 2014). Structural capital encompasses the corporate culture, technology systems, intellectual property, the management processes as well as the learning capacity that can create value for the organization (Alhassan and Asare, 2016) while relational capital is the build of relationships that any organization has with the external world (Meles et al., 2016). Despite having an array of IC measurement methods, this study will use VAIC since it is the most applied method in determining the IC efficiency. To add up, VAIC provides straightforward and uncomplicated procedure in measuring the value creation (Kehelwalatenna, 2016) as well as it can be applied regardless the size of organization (Joshi et al., 2010).

\subsection{Intellectual Capital and Corporate Governance}

As opined by Van der Meer-Kooistra and Zijlstra (2001) when an organization managing and controlling IC, it directly shows that the managers set up goals in respect of the utilization of IC. Therefore the top personnel namely board of directors should make apt strategies and policies to ascertain that the managers empower the employment of IC. Owing to that reason, indeed it is of prime importance to examine the characteristics of board of directors that can directly contribute to the higher IC efficiency. Concerning to empirical studies related to corporate governance and IC efficiency, there are substantially low amount of studies. More recently, Mubaraq and Haji (2014) found that the corporate governance attributes and ownership structure exert significant impact on at least one of the IC disclosure components namely human, internal and external capital. In the different note, Al-Musalli and Ismail (2012a) put an endeavor to analyze the determinants of intellectual capital efficiency where they tested the corporate governance measures as the explanatory variables and the findings suggest that the board size, number of independent directors, domestic strategic institutional ownership and family ownership affect significantly the intellectual capital efficiency. Meanwhile, focusing on the top service organizations in Australia, Appuhami and Bhuyan (2015) found that CEO duality, board composition through the proportion of independent directors and remuneration committee has significant positive relationship with IC efficiency. In recent discourse, Kamath (2019) discovered the negative impact of board size on IC efficiency of largecap organizations in India. So far, there are gaps identified in examining the characteristics of board of directors which can give impact to IC efficiency, thus it is worthwhile to extend the research pertinent to this notion. The governance measures that will be tested against efficiency as proposed in this study are as follow:

Board size: The board size refers to the number of members serving on the board. Theoretically, the larger boards can increase the amount of expertise on the board which will directly elevate the information processing capabilities of the board members (Al-Musalli and Ismail, 2012b). However, there is no uniform agreement on the most ideal board size as there are mixed findings from the past studies. Attarit (2016), indicated that board size asserts the positive impact on intellectual capital efficiency. On the other hand, AlMusalli and Ismail (2012b) tested board size against IC efficiency but the results show that there are no significant relationship between those variables.

Board expertise: This variable refers to the formal educational backgrounds of the board members in financing and accounting field of studies. As pinpointed by Saeed et al. (2015), the skills, knowledge and expertise of the directors individually will lead to a better performance. More precisely, possessing degrees in financing area can benefit the financing management of the organisation (Jeanjean and Stolowy, 2009). Notwithstanding, Darmadi (2013) in his study showed the significant negative relationship between the academic degrees in finance-related field with the organisational performance.

Female members: This variable signifies the representation of females in the board. According to Bao et al. (2014), some instances of women characteristics in top management are they are more socially oriented as compared with the men, they are more attentive to stakeholders and they are more likely to focus on non-financing aspect like customer satisfaction. Simply put, these qualities can bring positive impacts to IC efficiency. 
Nationality diversity: Similar to the study by Ruigrok et al. (2007), this variable refers to the foreigner representation on a board by examining the specific nationality of the members. As pinpointed by AlMusalli and Ismail (2012b), a demographic diversity equips the board members with an extended range of viewpoints and solutions that directly embellish the efficiency and effectiveness of the decision making of the board which will assist in building up the quality of actions taken by the firm.

Board meeting: The number of meetings held in a year by the bank can signify the active of the board. Vafeas (1999) opined that the activeness of the board where the board holds the meetings more regularly is more tend to conduct their responsibilities in favour of shareholders' interests. Eluyela et al. (2018) also stressed on the importance of board meeting to be conducted regularly as it can serve as an important medium for effective harmonization of the board members' opinions in attaining organizational objectives.

Primarily, the study seeks to examine the impact of corporate governance measures on VAIC and their components namely HCE, SCE, CEE and REE. Correspondingly, in order to fulfill the objective of this study, the following hypotheses are being tested.

Table 1. Summary of hypotheses

\begin{tabular}{|c|c|}
\hline \multicolumn{2}{|c|}{ Corporate Governance Measures and VAIC } \\
\hline H1: & $\begin{array}{l}\text { There is a significant positive relationship between board size (BSIZE) and value added intellectual capital } \\
\text { coefficient (VAIC) of Islamic banks. }\end{array}$ \\
\hline H2: & $\begin{array}{l}\text { There is a significant positive relationship between board expertise (BEXP) and value added intellectual } \\
\text { capital coefficient (VAIC) of Islamic banks. }\end{array}$ \\
\hline H3: & $\begin{array}{l}\text { There is a significant positive relationship between board female directors (BFEM) and value added } \\
\text { intellectual capital coefficient (VAIC) of Islamic banks. }\end{array}$ \\
\hline H4: & $\begin{array}{l}\text { There is a significant positive relationship between board meeting (BMEET) and value added intellectual } \\
\text { capital coefficient (VAIC) of Islamic banks. }\end{array}$ \\
\hline H5: & $\begin{array}{l}\text { There is a significant positive relationship between board nationality diversity (BNAT) and value added } \\
\text { intellectual capital coefficient (VAIC) of Islamic banks. }\end{array}$ \\
\hline \multicolumn{2}{|c|}{ Corporate Governance Measures and HCE } \\
\hline H6: & $\begin{array}{l}\text { There is a significant positive relationship between board size (BSIZE) and human capital efficiency (HCE) of } \\
\text { Islamic banks. }\end{array}$ \\
\hline H7: & $\begin{array}{l}\text { There is a significant positive relationship between board expertise (BEXP) and human capital efficiency (HCE) } \\
\text { of Islamic banks. }\end{array}$ \\
\hline H8: & $\begin{array}{l}\text { There is a significant positive relationship between board female directors (BFEM) and human capital } \\
\text { efficiency (HCE) of Islamic banks. }\end{array}$ \\
\hline H9: & $\begin{array}{l}\text { There is a significant positive relationship between board meeting (BMEET) and human capital efficiency } \\
\text { (HCE) of Islamic banks. }\end{array}$ \\
\hline H10: & $\begin{array}{l}\text { There is a significant positive relationship between board nationality diversity (BNAT) and human capital } \\
\text { efficiency (HCE) of Islamic banks. }\end{array}$ \\
\hline \multicolumn{2}{|c|}{ Corporate Governance Measures and SCE } \\
\hline H11: & $\begin{array}{l}\text { There is a significant positive relationship between board size (BSIZE) and structural capital efficiency (SCE) of } \\
\text { Islamic banks. }\end{array}$ \\
\hline H12: & $\begin{array}{l}\text { There is a significant positive relationship between board expertise (BEXP) and structural capital efficiency } \\
\text { (SCE) of Islamic banks. }\end{array}$ \\
\hline H13: & $\begin{array}{l}\text { There is a significant positive relationship between board female directors (BFEM) and structural capital } \\
\text { efficiency (SCE) of Islamic banks. }\end{array}$ \\
\hline H14: & $\begin{array}{l}\text { There is a significant positive relationship between board meeting (BMEET) and structural capital efficiency } \\
\text { (SCE) of Islamic banks. }\end{array}$ \\
\hline H15: & $\begin{array}{l}\text { There is a significant positive relationship between board nationality diversity (BNAT) and structural capital } \\
\text { efficiency (SCE) of Islamic banks. }\end{array}$ \\
\hline \multicolumn{2}{|c|}{ Corporate Governance Measures and CEE } \\
\hline H16: & $\begin{array}{l}\text { There is a significant positive relationship between board size (BSIZE) and capital employed efficiency (CEE) of } \\
\text { Islamic banks. }\end{array}$ \\
\hline H17: & There is a significant positive relationship between board expertise (BEXP) and capital employed efficiency \\
\hline
\end{tabular}




\begin{tabular}{|l|l|}
\hline H18: & (CEE) of Islamic banks. \\
\hline H19: & $\begin{array}{l}\text { There is a significant positive relationship between board female directors (BFEMt positive relationship between board meeting (BMEET) and capital employed efficiency } \\
\text { (CEE) of Islamic banks. }\end{array}$ \\
\hline H2O: & $\begin{array}{l}\text { There is a significant positive relationship between board nationality diversity (BNAT) and capital employed } \\
\text { efficiency (CEE) of Islamic banks. }\end{array}$ \\
\hline
\end{tabular}

\section{Methodology of research}

\subsection{Sample selection}

This current study is focusing on Islamic banks worldwide. Therefore, initially, the data are extracted from the Bankscope database. In the first stage of sample selection, there are 163 Islamic banks across 34 countries. However, due to the data availability, the final sample consists of a panel of 59 Islamic banks involving 19 countries, over the twelve-year period of 2006 to 2017. The governance variables which have been disclosed in the banks' annual reports are downloaded from banks' websites respectively. In essence, the samples encompassing the banks from South Asia countries which are Pakistan and Bangladesh, Southeast Asia countries namely Brunei, Indonesia, Malaysia and Thailand, Middle East countries namely Bahrain, Egypt, Jordan, Kuwait, Lebanon, Palestine, Qatar, Saudi Arabia, Tunisia, Turkey and United Arab Emirates, Southern Africa country which is South Africa and finally Northern Europe country namely United Kingdom. The country-wise sample distribution for this study is as presented in Table 1 where United Arab Emirates represents $13.56 \%$ of the overall samples, which is the highest, whilst Brunei, Thailand, Palestine, Lebanon, Tunisia and South Africa notably represent only $1.69 \%$ of the total samples each.

Table 2. Distribution of Sample Banks

\begin{tabular}{lcccc}
\hline Country & Total & Percentage (\%) & Observation & Percentage (\%) \\
\hline Bahrain & 5 & 8.48 & 55 & 9.8 \\
Bangladesh & 5 & 8.48 & 45 & 8.1 \\
Brunei & 1 & 1.69 & 6 & 1.1 \\
Egypt & 2 & 3.39 & 17 & 3.0 \\
Indonesia & 4 & 6.78 & 34 & 6.1 \\
Jordan & 2 & 3.39 & 19 & 3.4 \\
Kuwait & 4 & 6.78 & 48 & 8.6 \\
Lebanon & 1 & 1.69 & 5 & 0.9 \\
Malaysia & 7 & 11.86 & 73 & 13.1 \\
Pakistan & 5 & 8.48 & 48 & 8.6 \\
Palestine & 1 & 1.69 & 12 & 2.1 \\
Qatar & 4 & 5.78 & 39 & 7.0 \\
Saudi Arabia & 3 & 1.09 & 25 & 4.5 \\
South Africa & 1 & 1.69 & 9 & 1.6 \\
Thailand & 1 & 1.69 & 12 & 2.1 \\
Tunisia & 1 & 3.39 & 8 & 1.4 \\
Turkey & 2 & 13.56 & 73 & 2.9 \\
UAE & 8 & 3.39 & 15 & 2.1 \\
United Kingdom & 2 & $\mathbf{1 0 0}$ & $\mathbf{5 5 9}$ & $\mathbf{1 0 0 . 0}$ \\
Total & $\mathbf{5 9}$ & & &
\end{tabular}

\subsection{Dependent variables}

Aforementioned, intellectual capital efficiency is being selected as the dependent variable in this study. There are number of well-established measurements of intellectual capital efficiency but the most widely applied based on prior literatures is value-added intellectual coefficient which was established by Pulic (2000). VAIC is acknowledged to be the apropos measure to calculate the efficiency of intellectual capital where the higher value indicated the higher the utilization of intellectual capital of particular organization. Shih, Chang, and Lin (2010) highlighted in their study that one of the perks of VAIC is the data is easy to obtain whereby it can be measured facilely, thus the benefit also has precipitate the latter-day 
studies to apply VAIC in measuring IC efficiency (Meles et al., 2016; Ozkan et al., 2017; Tran and Vo, 2018). Specifically, the studies that examining the empirical linkage of corporate governance and intellectual capital efficiency have extensively applied VAIC as well. To add up, the convenient process of VAIC has gravitates this study to measure intellectual capital efficiency of Islamic banks using this applicable method. It is a consistent approach which composed of three sub-variants namely Human Capital Efficiency (HCE), Structural Capital Efficiency (SCE) and Capital Employed Efficiency (CEE). The items needed to compute VAIC and MVAIC can be collected on balance sheets and income statements. VAIC is the sum of HCE, SCE and CEE while MVAIC is the sum of HCE, SCE, CEE and relational capital efficiency (RCE). The formula as follows:

$$
\mathrm{VAIC}_{\mathrm{i}}=\mathrm{HCE}_{\mathrm{i}}+\mathrm{SCE}_{\mathrm{i}}+\mathrm{CCE}_{\mathrm{i}}
$$

Where VA can be measured by summing profit before tax and payroll expenses as computed by Tran and Vo (2018). HC refers to payroll expenses, while in attaining the value of SC, HC value is deducted from the value of VA. CE is measured by subtracting total assets from intangible assets.

\subsection{Independent variables}

The independent variables of this study involving corporate governance measures. As for this study, there are five governance measures will be tested against intellectual capital efficiency as the dependent variable. In line with previous studies, board size is measured by the total number of members assigned on the board of directors. Board expertise is measured by the proportion of directors with accounting experience and financing qualification to board size while board female directors is measured by the proportion of female board members during the year. Board meeting is measured by the numbers of meetings held in a year and board nationality is taken into account in CG variables by a dummy variable with the value of 1 is there is nationality diversity among the board members and value of 0 otherwise.

\subsection{Control variables}

Bank-specific variables namely bank size which proxied by natural logarithm of total bank's assets and bank's age which proxied by number of years since banks' incorporation are being used as the control variable. In addition, due to main reason in choosing the sample period which is from 2006-2017, the study included the impact of financing crisis dummy variable taking the value of 1 for 2008-2009 and 0 otherwise (M. A. Al-Musali and Ku Ismail, 2016; Kesse and Pattanayak, 2019). The study also includes governance index which published by WorldBank (2018) to control institutional differences performed by different countries as has been used by Quttainah et al. (2013). The summary of all variables that have been computed in this study are presented in Table 3. 
Table 3. Summary of Variables

\begin{tabular}{|c|c|c|c|}
\hline $\begin{array}{l}\text { Type of } \\
\text { Variable }\end{array}$ & Variable & $\begin{array}{l}\text { Abbreviation } \\
\text { of variable }\end{array}$ & Measurement \\
\hline \multirow[t]{5}{*}{ Dependent } & Value Added Intellectual & VAIC & $\mathrm{VAIC}=\mathrm{HCE}+\mathrm{SCE}+\mathrm{CEE}$ \\
\hline & Coefficient & & \\
\hline & Human Capital Efficiency & HCE & $\mathrm{HCE}=\mathrm{VA} / \mathrm{HC}$ \\
\hline & Structural Capital Efficiency & SCE & SCE $=$ SC/VA \\
\hline & Capital Employed Efficiency & CEE & $\mathrm{CEE}=\mathrm{VA} / \mathrm{CE}$ \\
\hline \multirow[t]{5}{*}{ Independent } & Bank size & BSIZE & $\begin{array}{l}\text { Total number of members assigned on the board } \\
\text { of directors }\end{array}$ \\
\hline & Board expertise & BEXP & $\begin{array}{l}\text { Number of directors with accounting experience } \\
\text { and financial qualification divided by total } \\
\text { numbers of board members }\end{array}$ \\
\hline & Board female directors & BFEM & $\begin{array}{l}\text { Number of female directors divided by total } \\
\text { numbers of board members }\end{array}$ \\
\hline & Board meeting & BMEET & Total number of meetings held in a year \\
\hline & Board nationality & BNAT & $\begin{array}{l}\text { Dummy variable with the value of } 1 \text { is there is } \\
\text { nationality diversity among the board members } \\
\text { and value of } 0 \text { otherwise }\end{array}$ \\
\hline \multicolumn{4}{|l|}{ Control } \\
\hline \multirow[t]{2}{*}{ Bank-specific } & Bank Size & SIZE & Log of total assets \\
\hline & Bank Age & AGE & Number of years since banks' incorporation \\
\hline \multirow[t]{2}{*}{$\begin{array}{l}\text { Macroecono } \\
\text { mic }\end{array}$} & Crisis & Crisis & $\begin{array}{l}\text { Dummy variable with the value of } 1 \text { for the year } \\
\text { of } 2008 \text { and } 2009 \text {, and zero otherwise }\end{array}$ \\
\hline & Governance index & GI & Worldwide governance index \\
\hline
\end{tabular}

\subsection{Regression Models}

In order to examine the relationship between corporate governance and intellectual capital efficiency, four regression models have been formed as viewable in Table 4. Model 1 indicated the linkage between VAIC and corporate governance measures while Model 2, 3, 4 decomposed the components of VAIC namely human capital efficiency, structural capital efficiency and capital employed efficiency in order to know the impact of corporate governance measures on individual components of VAIC. The regression models for this study as follows:

Table 4. Regression Models

\begin{tabular}{|c|c|c|}
\hline & Model & Function \\
\hline 1 & $\begin{array}{l}\text { VAIC }=f \text { (BSIZE, BEXP, BFEM, } \\
\text { BMEET, BNAT SIZE, AGE, Crisis) }\end{array}$ & $\begin{array}{l}+\beta_{2} \text { BSIZE }+\beta_{3} B E X P+\beta_{4} B F E M+\beta_{5} B M E E T+ \\
\quad+\beta_{10} \text { Crisis }+\varepsilon\end{array}$ \\
\hline 2 & $\begin{array}{l}\mathrm{HCE}=f( \\
\text { BMEET, BN }\end{array}$ & $\begin{array}{l}Q P+\beta_{4} B F E M+\beta_{5} B M E E T+\beta_{6} B N A T+ \\
\varepsilon\end{array}$ \\
\hline $\begin{array}{c}\text { Model } \\
3\end{array}$ & $\begin{array}{l}\text { SCE }=f(\mathrm{~B} \\
\text { BMEET, BN }\end{array}$ & $\begin{array}{l}X P+\beta_{4} B F E M+\beta_{5} B M E E T+\beta_{6} B N A T+ \\
\varepsilon\end{array}$ \\
\hline $\begin{array}{c}\text { Mode } \\
4\end{array}$ & $\begin{array}{l}\mathrm{EE}=f(\mathrm{BSIZE}, \mathrm{BEXP}, \mathrm{BFEM}, \\
\text { MEET, BNAT SIZE, AGE, Crisis) }\end{array}$ & $\begin{array}{c}C E E=\beta_{1}+\beta_{2} B S I Z E+\beta_{3} B E X P+\beta_{4} B F E M+\beta_{5} B M E E T+\beta_{6} B N A T+ \\
+\beta_{10} \text { Crisis }+\varepsilon\end{array}$ \\
\hline
\end{tabular}

Notes: VAIC, HCE, SCE, CEE are value-added intellectual coefficient, human capital efficiency, structural capital efficiency and capital employed efficiency. Governance variables proxy by BSIZE, BEXP, BFEM, BMEET, BNAT are total number of members assigned on the board of directors, the proportion of directors with accounting experience and financial qualification to board size, the proportion of female 
board members during the year., numbers of meetings held in a year and a dummy variable with the value of 1 is there is nationality diversity among the board members and value of 0 otherwise, respectively. SIZE, $\mathrm{AGE}, \mathrm{Gl}, \mathrm{Crisis}$ are natural logarithm of total assets, number of years since banks' incorporation, governance index and dummy variable with the value of 1 for the year of 2008 and 2009 and 0 for otherwise respectively.

\section{Results and Findings}

\subsection{Descriptive Statistics}

Table 5 presents the descriptive statistics of governance variables as independent variables along with VAIC and its three components as dependent variable accompanied with three control variables. Based on the table 5, the mean value of VAIC is 3.560. In contrast to other studies, the mean value of VAIC in this study is higher than the mean value of VAIC of the banks that are operating in Thailand (0.683) (Tran and Vo, 2018) banks in Ghana (2.088) (Alhassan and Asare, 2016) and banks in Tanzania (2.738) and it is slightly lower than the mean value of VAIC of the banks that are operating in Indonesia (3.636) and Turkey (3.887) (Ozkan et al., 2017). In the same manner when compared with the study conducted by Nawaz (2017) on Islamic banks operating in 21 countries, the mean value of VAIC in this study also is slightly lower (3.93). The negative signs of the values of IC variables demonstrate that the costs borne by the banks in investing IC more than what IC can assist in improving the banks' performance (Kesse and Pattanayak, 2019). Focusing on mean of VAIC which recorded 3.560 shows that, in average, the sampled Islamic banks are able to utilize intellectual capital resources efficiently with positive trend. It is noting that HCE is the component that contributes highest to the value of IC as compared to SCE and CEE with the average value of 2.756. The mean of proportion of female members on the board is low which recorded only 0.050 while the mean number of meetings that held in a year is 8.6 which was slightly higher than the mean number of meetings recorded by Grassa and Matoussi (2014) which is 7.04.

Table 5. Descriptive Statistics of Variables

\begin{tabular}{lcccc}
\hline & Minimum & Maximum & Mean & Std. Deviation \\
\hline VAIC & -2.660 & 10.563 & 3.560 & 2.018 \\
HCE & -4.061 & 9.660 & 2.756 & 1.812 \\
SCE & -2.840 & 9.167 & 0.561 & 0.616 \\
CEE & -0.010 & 6.229 & 0.244 & 0.716 \\
BSIZE & 4.000 & 23.000 & 9.160 & 2.916 \\
BEXP & 0.250 & 1.000 & 0.675 & 0.169 \\
BFEM & 0.000 & 0.500 & 0.050 & 0.087 \\
BMEET & 0.000 & 30.000 & 8.610 & 5.047 \\
BNAT & 0.000 & 1.000 & 0.520 & 0.500 \\
SIZE & 9.540 & 18.332 & 14.906 & 1.564 \\
AGE & 0.000 & 60.000 & 18.470 & 13.372 \\
GI & -1.196 & 1.867 & 0.207 & 0.624 \\
\hline
\end{tabular}

Source: Author's calculation

\subsection{Diagnostic Checks}

Pearson correlation analysis has been conducted as a way to identify the potential multicollinearity issue in the regression model. The test can examine whether there is any strong correlations between these independent variables. Based on the results as shown in Table 6, there is no strong correlation between corporate governance variables as the proxies of independent variables. 
Table 6. Correlation Matrix

\begin{tabular}{|c|c|c|c|c|c|c|c|c|}
\hline & BSIZE & BEXP & BFEM & BMEET & BNAT & SIZE & AGE & $\mathrm{Gl}$ \\
\hline BSIZE & 1.000 & & & & & & & \\
\hline BEXP & -0.064 & 1.000 & & & & & & \\
\hline BFEM & -0.009 & 0.022 & 1.000 & & & & & \\
\hline BMEET & 0.303 & -0.151 & 0.218 & 1.000 & & & & \\
\hline BNAT & -0.101 & 0.274 & -0.264 & -0.386 & 1.000 & & & \\
\hline SIZE & -0.026 & -0.063 & -0.042 & 0.104 & -0.050 & 1.000 & & \\
\hline AGE & 0.169 & -0.126 & -0.233 & 0.000 & 0.052 & 0.314 & 1.000 & \\
\hline GI & -0.465 & 0.136 & -0.061 & -0.256 & 0.322 & 0.319 & -0.116 & 1 \\
\hline
\end{tabular}

Source: Author's calculation

Subsequent to multicollinearity test, with respect to panel data analysis, Breusch and Pagan Langrangian Multiplier test (Breusch and Pagan, 1980) has been applied to test whether pooled OLS is adequate as compared to random effect estimation. The result shows that the variance of the individualspecific effects is not equal to zero; therefore, pooled OLS estimation is rejected. In brief, it is not advisable to use pooled OLS estimation since it will provide less valid inference. Afterwards, in order to decide whether to estimate using random-effects estimator or fixed-effects estimator, Hausman test (Hausman, 1978) has been applied where the study found that the latter is the best estimator to produce more robust and valid results. It is because as explained by Frondel and Vance (2010) the former is preferable if and only if the correlation between individual-specific effects and $X$ or variables in the regression model is zero. Nonetheless, after running Hausman test, the assumption is unfulfilled. Besides, of crucial importance in examining the existence of heteroskedasticty and autocorrelation issues in the models. After applying Modified Wald test for heteroskedasticity and Woolridge test for serial correlation, the study found that the regression models suffer both heteroskedasticity and autocorrelation. Therefore, in order to attain valid inference, the study apply remedial measure namely robust standard errors, and one of the benefits of this measure is the robust heteroskedasticity-consistent standard errors are produced (Kesse and Pattanayak, 2019).

\subsection{Regression Results}

The regression results concerning of Model 1, 1a, 2, 2a, 3, 3a, 4 and $4 a$ which examining the relationship between corporate governance variables and IC efficiency of selected Islamic banks within the period of 2006 until 2017 are presented in Table 7, 8, 9, 10. Based on the regression results in Table 7, it is clear shows that there is a positive and statistically significant between one of corporate governance variables which is board expertise and VAIC as the proxy of IC efficiency which supports the hypothesis aforementioned that the banks with higher proportion of board of directors that possessing financial and accounting expertise have higher IC efficiency. Turning to the regression results in Model 1a which has included the control variables namely SIZE, AGE, GI and crisis shows the very similar findings as in Model 1 whereby it is worth noting that board expertise has significant positive relationship with IC efficiency. This result is directly implies that the financial or accounting knowledge that possessing by the board of directors has affect positively the utilization of intellectual capital.

Table 7. Regression Results (Dependent Variable: VAIC)

\begin{tabular}{lcc}
\hline \multicolumn{1}{c}{ Independent variables } & Model 1 & Model 1a \\
\hline C & $3.296^{* * *}(1.053)$ & $6.511(4.875)$ \\
BSIZE & $-0.113(0.107)$ & $-0.093(0.096)$ \\
BEXP & $1.553^{* * *}(0.618)$ & $1.668^{* * *}(0.631)$ \\
BFEM & $0.106(3.148)$ & $1.564(3.134)$ \\
BMEET & $0.033(0.041$ & $0.027(0.039)$ \\
BNAT & $-0.337(0.393)$ & $-0.625(0.381)$ \\
SIZE & & $-0.089(0.375)$ \\
AGE & & $-0.108(0.057)$ \\
GI & & $0.802(0.495)$ \\
Crisis & & $-0.409(0.255)$ \\
Adjusted $\mathbf{R}^{2}$ & & 0.083 \\
\hline
\end{tabular}


Note: The numbers in the parentheses are the robust standard errors because the models suffer heteroskedasticity and autocorrelation. Hausman tests are being applied in determining the best estimator for regression models. All models using one way individual-specific fixed-effect. ${ }^{* * *}, * *, *$ represent statistical significance at $1 \%, 5 \%, 10 \%$ respectively.

Model 2, 2a, 3, 3a, 4 and 4a shows the results when VAIC is split into its three components namely HCE, SCE and CEE with and without control variables to further investigate the impact of corporate governance variables on the individual components of VAIC. Table 8 presents HCE as the independent variable in regression model where it shows only the proportion of members who have knowledge about financial and accounting on the board has significant positive relationship with HCE. The finding suggests the higher the proportion of financial and accounting expertise on the board, the better the utilization of human capital for Islamic banks. The results are similar when including control variables where the board expertise has significant positive relationship with HCE. It also can be found that nationality diversity on the board affect negatively HCE. Simply put, when the board has the dissimilarity in terms of nationality background, it brings negative effects on team performance when it comes to elevate the human capital efficiency. Besides, the age of the bank as one of the control variables, have statistically significant negative relationship with HCE which indicates the longer the age of the bank, the lower the HCE.

Table 8. Regression Results (Dependent Variable: HCE)

\begin{tabular}{lcc}
\hline \multicolumn{1}{c}{ Independent variables } & Model 2 & Model 2a \\
\hline C & $2.569^{* *}(0.838)$ & $1.306(4.657)$ \\
\hline BSIZE & $-0.057(0.086)$ & $-0.046(0.077)$ \\
\hline BEXP & $0.778^{*}(0.444)$ & $0.992^{* *}(0.478)$ \\
\hline BFEM & $-0.667(2.953)$ & $0.788(2.825)$ \\
\hline BMEET & $0.038(0.041)$ & $0.037(0.039)$ \\
\hline BNAT & $-0.364(0.339)$ & $-0.666^{*}(0.364)$ \\
\hline SIZE & & $0.243(0.347)$ \\
\hline AGE & & $-0.130^{* * *}(0.050)$ \\
\hline GI & & $0.389(0.451)$ \\
\hline Crisis & & $-0.235(0.234)$ \\
\hline Adjusted $\mathbf{R}^{2}$ & 0.013 & 0.072 \\
\hline
\end{tabular}

Note: The numbers in the parentheses are the robust standard errors because the models suffer heteroskedasticity and autocorrelation. Hausman tests are being applied in determining the best estimator for regression models. All models using one way individual-specific fixed-effect. ${ }^{* * *},{ }^{* *},{ }^{*}$ represent statistical significance at $1 \%, 5 \%, 10 \%$ respectively.

Corporate governance variables also have been tested against the second component of VAIC which is SCE as demonstrated in Table 9. Consonant to the findings show in the prior model, without control variables, the board members who have financial or accounting expertise affect positively SCE. The similar findings can be notably found when including control variables in the regression model pertinent to BEXP while additionally, supporting the hypothesis aforementioned, the representation of female members on the board also has significant positive relationship with SCE. It seems to imply that the female board members in Islamic banks contribute positively in utilizing structural capital efficiency like the usage of software, patents, licenses and so forth. In respect of control variables, crisis has significant negative relationship with SCE where it implies that the presence of crisis on 2008 to 2009 indeed brings negative effect to the utilization of SCE for Islamic banks. Meanwhile in respect of the regression model where CEE as the independent variable, all the corporate governance variables is not found to influence CEE in Islamic banks. 
Table 9. Regression Results (Dependent Variable: SCE)

\begin{tabular}{lcc}
\hline \multicolumn{1}{c}{ Independent variables } & Model 3 & Model 3a \\
\hline C & $0.103(0.332)$ & $0.472(2.299)$ \\
\hline BSIZE & $-0.014(0.015)$ & $-0.015(0.012)$ \\
\hline BEXP & $0.751^{* *}(0.383)$ & $0.809^{* *}(0.352)$ \\
\hline BFEM & $0.660(0.425)$ & $0.786^{*}(0.429)$ \\
\hline BMEET & $-0.007(0.007)$ & $-0.011(0.008)$ \\
\hline BNAT & $0.076(0.165)$ & $0.088(0.167)$ \\
\hline SIZE & & $-0.016(0.183)$ \\
\hline AGE & & $-0.008(0.021)$ \\
\hline GI & & $0.222(0.184)$ \\
\hline Crisis & & $-0.211^{* *}(0.086)$ \\
\hline Adjusted $\mathbf{R}^{2}$ & 0.017 & 0.033 \\
\hline
\end{tabular}

Note: The numbers in the parentheses are the robust standard errors because the models suffer heteroskedasticity and autocorrelation. Hausman tests are being applied in determining the best estimator for regression models. All models using one way individual-specific fixed-effect. ${ }^{* * *},{ }^{* *}, *$ represent statistical significance at $1 \%, 5 \%, 10 \%$ respectively.

Table 10. Regression Results (Dependent Variable: CEE)

\begin{tabular}{lcc}
\hline \multicolumn{1}{r}{ Independent variables } & Model 4 & Model 4a \\
\hline C & $0.803^{* * *}(0.316)$ & $4.458^{*}(2.380)$ \\
\hline BSIZE & $-0.051(0.031)$ & $-0.042(0.033)$ \\
\hline BEXP & $-0.130(0.212)$ & $-0.271(0.259)$ \\
\hline BFEM & $0.056(0.276)$ & $-0.056(0.321)$ \\
\hline BMEET & $0.003(0.007)$ & $0.003(0.006)$ \\
\hline BNAT & $-0.031(0.074)$ & $-0.035(0.077)$ \\
\hline SIZE & & $-0.279(0.168)$ \\
\hline AGE & & $0.026(0.014)$ \\
\hline GI & & $0.143(0.093)$ \\
\hline Crisis & & $0.028(0.043)$ \\
\hline Adjusted R & & 0.086 \\
\hline
\end{tabular}

Note: The numbers in the parentheses are the robust standard errors because the models suffer heteroskedasticity and autocorrelation. Hausman tests are being applied in determining the best estimator for regression models. All models using one way individual-specific fixed-effect. ${ }^{* * *},{ }^{* *},{ }^{*}$ represent statistical significance at $1 \%, 5 \%, 10 \%$ respectively.

\section{Conclusions}

Immediately above, the results provided might prove beneficial especially for Islamic banks in order to identify what are the characteristics that can affect positively the utilization of IC and its components. It is because as reported, the proportion of board members who have financial and accounting expertise can affect positively the efficiency of intellectual capital.

Additionally, based on regression results of individual components of IC, in concert with the findings when VAIC as the independent variable, the higher the proportion of board members who possess financing and accounting expertise, the higher the HCE and SCE. The result suggests the board members who have strong knowledge about financing and accounting, will be able to make relevant strategies and decisions in utilizing their human and structural capital resources vigorously. It is also remarkably found that the existence of female board members on the board has significant contribution to the employment of SCE. The result suggests the inclusion of female members on the board necessitate for the betterment of SCE. Nonetheless, there is no empirical evidence to show that the board characteristics that have been tested in this study have significant relationship with CEE.

The limitations of this study are the small sample size due to data availability and the criticisms argued by other studies towards VAIC methodology. To augment the development of IC in banking sector 
especially to ascertain the determinants that can contribute to intellectual capital efficiency, more future researches have to be conducted especially for Islamic banks. The continuous endeavours have to put forth since Islamic banks are expected to possess more knowledgeable employees and higher technology systems. It is because they have to produce more complicated products which is to be aligned with Shariah law as well as they have to compete against the long-established conventional banks. So, the future research can extend the study with larger sample of Islamic banks or classify the Islamic banks based on bank types either it is domestic or foreign banks in order to get more valuable findings. In terms of methodology to measure IC, as suggested by Appuhami and Bhuyan (2015), the future studies can explore a model that can measure IC more precisely.

\section{References}

1. Rashid, A., Ibrahim, K. M., Othman, R., \& See, F. K. (2012). IC disclosures in IPO prospectuses: evidence from Malaysia. Journal of Intellectual Capital, 13(1), 57-80.

2. Al-Musali, M. A., \& Ismail, K. N. I. (2016). Cross-country comparison of intellectual capital performance and its impact on financial performance of commercial banks in GCC countries. International Journal of Islamic and Middle Eastern Finance and Management, 9(4), 512-531.

3. Al-Musali, M. A. K. M., \& Ismail, K. N. I. (2015). Board diversity and intellectual capital performance: The moderating role of the effectiveness of board meetings. Accounting Research Journal, 28(3), 268-283.

4. Al-Musalli, M. A. K., \& Ismail, K. N. I. K. (2012a). Corporate Governance, Bank Specific Characteristics, Banking Industry Characteristics, And Intellectual Capital (Ic) Performance Of Banks In Arab Gulf Cooperation Council (Gcc) Countries. Asian Academy of Management Journal of Accounting \& Finance, 8.

5. Al-Musalli, M. A. K., \& Ismail, K. N. I. K. (2012b). Intellectual capital performance and board characteristics of GCC banks. Procedia Economics and Finance, 2, 219-226.

6. Alhassan, A. L., \& Asare, N. (2016). Intellectual capital and bank productivity in emerging markets: evidence from Ghana. Management Decision, 54(3), 589-609.

7. Amin, S., \& Aslam, S. (2017). Intellectual Capital, Innovation and Firm Performance of Pharmaceuticals: A Study of the London Stock Exchange. Journal of Information \& Knowledge Management, 16(02), 1750017.

8. Appuhami, R., \& Bhuyan, M. (2015). Examining the influence of corporate governance on intellectual capital efficiency: Evidence from top service firms in Australia. Managerial Auditing Journal, 30(4/5), 347-372.

9. Attarit, T. (2016). Analysis of mediating effect of intellectual capital efficiency linking board of directors' characteristics and firm performance: Empirical evidence from thai listed companies. Rajamangal University of Technology Thanyaburi. Faculty of Business Administration.

10.Bao, S., Fainshmidt, S., Nair, A., \& Vracheva, V. (2014). Women in upper echelons of management, tenure and legal risk. British Journal of Management, 25(2), 388-405.

11.Barney, J., Wright, M., \& Ketchen, J. D. J. (2001). The resource-based view of the firm: Ten years after 1991. Journal of Management, 27(6), 625-641.

12.Breusch, T. S., \& Pagan, A. R. (1980). The Lagrange multiplier test and its applications to model specification in econometrics. The Review of Economic Studies, 47(1), 239-253.

13.Darmadi, S. (2013). Board members' education and firm performance: evidence from a developing economy. International Journal of Commerce and Management, 23(2), 113-135.

14.Dimitropoulos, P. E., \& Koumanakos, E. (2015). Intellectual capital and profitability in European football clubs. International Journal of Accounting, Auditing and Performance Evaluation, 11(2), 202-220.

15.Edvinsson, L., \& Stenfelt, C. (1999). Intellectual capital of nations-for future wealth creation. Journal of Human Resource Costing \& Accounting, 4(1), 21-33.

16. Eluyela, D. F., Akintimehin, O. O., Okere, W., Ozordi, E., Osuma, G. O., Ilogho, S. O., \& Oladipo, O. A. (2018). Board meeting frequency and firm performance: examining the nexus in Nigerian deposit money banks. Heliyon, 4(10), e00850. 
17.Frondel, M., \& Vance, C. (2010). Fixed, random, or something in between? A variant of Hausman's specification test for panel data estimators. Economics Letters, 107(3), 327-329.

18.Grassa, R., \& Matoussi, H. (2014). Corporate governance of Islamic banks: a comparative study between GCC and Southeast Asia countries. International Journal of Islamic and Middle Eastern Finance and Management, 7(3), 346-362.

19. Hausman, J. A. (1978). Specification tests in econometrics. Econometrica: Journal of the Econometric Society, 1251-1271.

20.Jeanjean, T., \& Stolowy, H. (2009). Determinants of board members' financial expertiseEmpirical evidence from France. The International Journal of Accounting, 44(4), 378-402.

21.Joshi, M., Cahill, D., \& Sidhu, J. (2010). Intellectual capital performance in the banking sector: An assessment of Australian owned banks. Journal of Human Resource Costing \& Accounting, 14(2), 151-170.

22.Kamath, B. (2019). Impact of corporate governance characteristics on intellectual capital performance of firms in India. International Journal of Disclosure and Governance, 1-17.

23.Keenan, J., \& Aggestam, M. (2001). Corporate governance and intellectual capital: some conceptualisations. Corporate Governance: An International Review, 9(4), 259-275.

24.Kehelwalatenna, S. (2016). Intellectual capital performance during financial crises. Measuring Business Excellence, 20(3), 55-78.

25.Kesse, G. O., \& Pattanayak, J. (2019). Does investing in Intellectual Capital improve productivity? Panel evidence from commercial banks in India. Borsa Istanbul Review.

26.Ljubojevic, C., Ljubojevic, G., \& Maksimovic, N. (2013). Corporate Governance and Competitive Capability in Serbian Companies. Paper presented at the MIC 2013: Industry, Science and Policy Makers for Sustainable Future; Proceedings of the 14th International Conference, Koper, 21-23 November 2013 [Selected Papers].

27.Meles, A., Porzio, C., Sampagnaro, G., \& Verdoliva, V. (2016). The impact of the intellectual capital efficiency on commercial banks performance: Evidence from the US. Journal of Multinational Financial Management, 36, 64-74.

28. Mention, A.-L. (2012). Intellectual capital, innovation and performance: A systematic review of the literature. Business and Economic Research, 2(1).

29. Mohammad, H. S., Bujang, I., \& Hakim, T. A. (2018). The Impact of Intellectual Capital on Financial Performance of Malaysian Construction Firms. International Journal of Academic Research in Business and Social Sciences, 8(5), 173-186.

30. Mubaraq, S., \& Haji, A. A. (2014). The impact of corporate governance attributes on intellectual capital disclosure: A longitudinal investigation of Nigerian banking sector. Journal of Banking Regulation, 15(2), 144-163.

31.Nawaz, T. (2017). Intellectual Capital, Financial Crisis and Performance of Islamic Banks: Does Shariah Governance Matter? International Journal of Business and Society, 18(1), 211.

32.Nawaz, T., \& Haniffa, R. (2017). Determinants of financial performance of Islamic banks: An intellectual capital perspective. Journal of Islamic Accounting and Business Research, 8(2), 130-142.

33.Nimtrakoon, S. (2015). The relationship between intellectual capital, firms' market value and financial performance: Empirical evidence from the ASEAN. Journal of intellectual capital, 16(3), 587-618.

34.Ozkan, N., Cakan, S., \& Kayacan, M. (2017). Intellectual capital and financial performance: A study of the Turkish Banking Sector. Borsa Istanbul Review, 17(3), 190-198.

35.Pourmozafari, A., Heyrani, F., \& Moeinadin, M. (2014). The Examination of Relationship between Intellectual Capital and Financial Performance According to the Modulating Role of Competitive Advantage. International Journal of Academic Research in Accounting, Finance and Management Sciences, 4(1), 188200.

36.Pulic, A. (2000). VAIC ${ }^{\mathrm{TM}}$-an accounting tool for IC management. International journal of technology management, 20(5-8), 702-714.

37.Quttainah, M. A., Song, L., \& Wu, Q. (2013). Do Islamic banks employ less earnings management? Journal of International Financial Management \& Accounting, 24(3), 203-233.

38. Roos, J. (1998). Exploring the concept of intellectual capital (IC). Long Range Planning, 31(1), 150153. 
39.Ruigrok, W., Peck, S., \& Tacheva, S. (2007). Nationality and gender diversity on Swiss corporate boards. Corporate Governance: An International Review, 15(4), 546-557.

40.Saeed, S., Rasid, S. Z. A., \& Basiruddin, R. (2015). The mediating role of Intellectual capital in corporate governance and the corporate performance relationship. Mediterranean Journal of Social Sciences, 6(5), 209.

41.Saeed, S., Rasid, S. Z. A., \& Basiruddin, R. (2016). Relationship between intellectual capital and corporate performance of top Pakistani companies: an empirical evidence. International Journal of Learning and Intellectual Capital, 13(4), 376-396.

42.Shih, K.-H., Chang, C.-J., \& Lin, B. (2010). Assessing knowledge creation and intellectual capital in banking industry. Journal of Intellectual Capital, 11(1), 74-89.

43.Soheyli, F., Moeinaddin, M., \& Nayebzadeh, S. (2014). The Relationship between components of intellectual capital and performance of Yazd tile companies. International Journal of Academic Research in Accounting, Finance and Management Sciences, 4(1), 319-330.

44.Tran, D. B., \& Vo, D. H. (2018). Should bankers be concerned with Intellectual capital? A study of the Thai banking sector. Journal of Intellectual Capital, 19(5), 897-914.

45.Vafeas, N. (1999). Board meeting frequency and firm performance. Journal of financial economics, 53(1), 113-142.

46.Meer-Kooistra, V. D. J., \& Zijlstra, S. M. (2001). Reporting on intellectual capital. Accounting, Auditing \& Accountability Journal, 14(4), 456-476.

47.WorldBank. (2018). Worldwide Governance Indicators. Retrieved from https://info.worldbank.org/governance/wgi/\#home 